\title{
Correction to: A common source for the destructive earthquakes in the volcanic island of Ischia (Southern Italy): insights from historical and recent seismicity
}

\author{
Stefano Carlino ${ }^{1}$ (D) Nicola Alessandro Pino ${ }^{1} \cdot$ Anna Tramelli $^{1} \cdot$ Vincenzo De Novellis $^{2}$. \\ Vincenzo Convertito ${ }^{1}$
}

Published online: 1 April 2021

(c) Springer Nature B.V. 2021

\section{Correction to: Natural Hazards https://doi.org/10.1007/s11069-021-04675-z}

The article was published with missing corrections in Table 2. The original article has been corrected.

Publisher's Note Springer Nature remains neutral with regard to jurisdictional claims in published maps and institutional affiliations.

The original article can be found online at https://doi.org/10.1007/s11069-021-04675-z.

Stefano Carlino

stefano.carlino@ingv.it

1 INGV-Istituto Nazionale di Geofisica e Vulcanologia, Sezione di Napoli-Osservatorio Vesuviano, Via Diocleziano, 328, 80124 Napoli, Italy

2 IREA-CNR Istituto per iI Rilevamento Elettromagnetico dell'Ambiente, Naples, Italy 